\title{
Macrophage Colony-Stimulating Factor 1 Receptor
}

National Cancer Institute

\section{Source}

National Cancer Institute. Macrophage Colony-Stimulating Factor 1 Receptor. NCI

Thesaurus. Code C17392.

Macrophage colony-stimulating factor 1 receptor $(972 \mathrm{aa}, \sim 108 \mathrm{kDa}$ ) is encoded by the human CSF1R gene. This protein plays a role in protein phosphorylation, macrophage differentiation, and the regulation of cell proliferation. 